\title{
APLIKASI PEREKRUTAN DAN PENGELOLAAN ANGGOTA BERBASIS E-COMMERCE PADA KEGIATAN MULTI LEVEL MARKETING ORIFLAME
}

\author{
Fitra Nugraha ${ }^{1}$, Fresy Novian Desy ${ }^{2}$ \\ Fakultas Ilmu Komputer Universitas Kuningan \\ Jalan Tjut Nyak Dhien Cijoho Kuningan Telepon (0232) 873696 Fax. (0232) 874824 \\ fitra.nugraha@gmail.com ${ }^{1}$,fresy.novian.desy@gmail.com ${ }^{2}$
}

\begin{abstract}
Abstrak
Bisnis yang baik adalah bisnis dimana faktor utamanya membuka peluang untuk semua orang dapat bergabung dalam bisnis tersebut. Bisnis yang baik akan menghasilkan Sumber Daya Manusia yang bermental juara, salah satunya adalah bisnis di Multi Level Marketing Oriflame. Bisnis MLM Oriflame ini memberi banyak peluang bagi siapa saja untuk bergabung dan mengembangkan bisnis ini seluas mungkin. Dalam dunia Bisnis, ada berbagai macam jenis bisnis, tapi untuk Bisnis Di Multilevel Marketing tidak terlalu menghabiskan banyak Infestasi keungan. Melainkan hanya berfikir positif, mencari peluang, dan bermental juara. Oleh karena itu dituangkan suatu ide untuk membuat perekrutan dan pengelolaan anggota berbasis ECommerce. Member diharapkan dapat mengembangkan jaringan dengan seluas mungkin, dan dapat terus mengelola grupnya dengan baik, khususnya untuk member di daerah - daerah yang jauh dari kantor cabang.
\end{abstract}

Kata kunci : Perekrutan, Pengelolaan, Bisnis, MLM, E-Commerce, Oriflame

\section{Pendahuluan}

Peranan bisnis sangat penting dalam kehidupan masyarakat, karena melalui kegiatan bisnis suatu perusahaan akan dapat memenuhi setiap kebutuhan, keinginan dari konsumen yang beraneka ragam, sehingga konsumen merasa terpuaskan. Bisnis yang baik akan menghasilkan keuntungan dan kepuasan terhadap konsumen dan rekan bisnisnya dengan baik berupa barang ataupun jasa.

Pada era Globalisasi, bisnis sangat dibutuhkan tetapi kendala terbesar yang dialami oleh pembisnis adalah modal. Menjalankan bisnis dengan cara Network Marketing adalah salah satu alternatifnya, selain dapat membangun kerja sama yang baik tetapi juga memperluas wawasan.

Pada masa sekarang ini banyak yang menggeluti bisnis dengan jenis Network Marketing karena memberikan keuntungan yang sangat besar dan mudah dalam pengembangannya contohnya adalah perusahaan oriflame. Hanya saja masih ada beberapa proses bisnis yang dikerjakan secara semi manual, membutuhkan biaya besar, waktu yang tidak efektif serta keterbatasan wilayah. Sehingga dibutuhkan sistem yang lebih efektif dan efisien untuk meningkatkan kinerja Networks Marketing dari setiap jenjang karir seseorang atau kelompok yang menggeluti bisnis ini.

Dalam dunia bisnis Network Marketing adalah sistem penjualan yang memanfaatkan konsumen sebagai tenaga penyalur secara langsung. Harga barang yang ditawarkan di tingkat konsumen adalah harga produksi ditambah komisi yang menjadi hak konsumen karena secara tidak langsung telah membantu kelancaran distribusi. Adapun masalah yang muncul, di Network Marketing keanggotaannya ada dua peran yaitu Sponsor atau perekrut sebagai (upline) dan yang di rekrut sebagai 
(downline), tetapi cara perekrutan data anggota masih manual, masih menggunakan mesin Fax untuk mengirimkan data pribadi seorang anggota. Permasalahan yang muncul adalah ketika melakukan pendaftaran harus melalui upline yang sedang order. Dan yang menjadi masalah ketika jarak downline itu jauh dari tempat tinggal seorang yang menjadi sponsornya atau uplinenya. Sehingga mereka memakan waktu yang sangat tidak efektif ketika pendaftaran jarak jauh dan tentunya pengeluaran dari biaya Fax.

Oleh karena itu, dituangkan suatu ide untuk membuat pendaftaran member pada keanggotaan Oriflame yang dikelola oleh upline nya dengan berbasis Online. Upline diharapkan mempercepat pekerjaanya tanpa batas waktu dan tempat tinggal khusus nya mereka yang di Perusahaan Oriflame yang membernya minimal dari Level Newmanager untuk menggunakan fasilitas berupa Aplikasi member Online..

\section{Identifikasi Masalah}

Berdasarkan latar belakang di atas, maka dapat diidentifikasi permasalahan yang muncul adalah :

1. Proses perekrutan Member masih dilakukan secara semi manual yaitu menggunakan mesin fax.

2. Jangkauan perekrutan member kurang luas dikarenakan terbatas oleh wilayah dan pelayanannya terbatas oleh waktu (harus menunggu waktu kesediaan dari perekrutt member atau upline)

3. Informasi yang dapat diberikan mengenai bisnis MLM dan pengembangannya sangat terbatas karena hanya diperoleh dari perekrut member (upline).

4. Kurangnya sarana komunikasi antara upline atau perekrut member dengan downline atau yang direkrut.

\section{Batasan Masalah}

Berdasarkan identifikasi masalah di atas, maka penulis akan membatasi hal-hal yang berhubungan dalam pembuatan sistem dan program, diantaranya adalah :
1. Perekrutan member dapat dilakukan menggunakan web berbasis ecommerce.

2. Pemesanan produk dan perhitungan point member juga dilakukan menggunakan web tersebut.

\section{Metode Penelitian}

\subsection{Metode Pengembangan Sistem}

Metodologi pengembangan sistem yang digunakan adalah Model Waterfall. Model ini melakukan pengembangan sistem secara sistematis dan berurutan, mulai dari level kebutuhan sistem lalu menuju ke tahap analisis, desain, coding, testing / Verification, dan maintenance. Disebut dengan waterfall karena setiap tahap harus diselesaikan sampai tuntas sebelum melakukan tahap selanjutnya dan harus diproses secara berurutan.

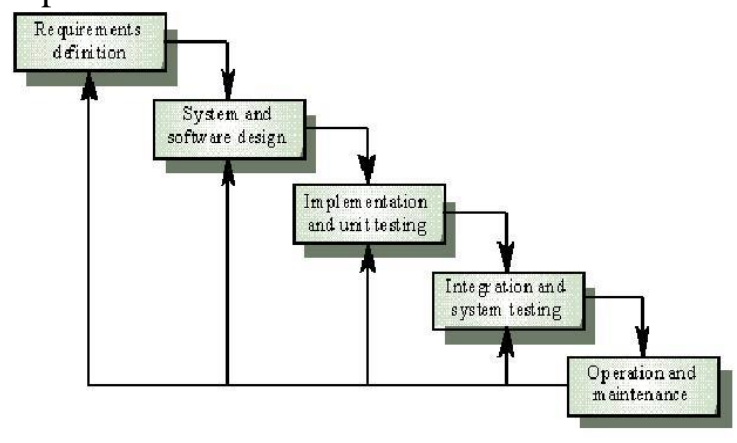

Gambar 1.1 Model Waterfall

Tahap-tahap Model Waterfall adalah :

1. Analisis dan Kebutuhan sistem

2. Perancangan sistem dan Perangkat lunak

3. Implementasi dan unit Testing

4. Integrasi dan Sistem Testing

5. Operasi dan Perawatan

Gambar di atas adalah tahapan umum dari model proses ini. Akan tetapi Roger S. Pressman memecah model ini menjadi 6 tahapan meskipun secara garis besar sama dengan tahapan-tahapan model waterfall pada umumnya.

Berikut adalah penjelasan dari tahaptahap yang dilakukan di dalam model ini menurut Pressman:

\section{System / Information Engineering and Modeling.}

2. Software Requirements Analysis.

3. Design. 
4. Coding.

5. Testing / Verification.

6. Maintenance.

\subsection{Teknik Pengumpulan Data}

Penulis menggunakan beberapa teknik yang digunkan untuk memperoleh data dan informasi yang akurat, yaitu :

1. Observasi

Pengamatan yang dilakukan dengan cara meninjau secara langsung keadaan mengenai proses bisnis dan sistem yang berjalan pada perusahaan oriflame.

2. Wawancara

Penulis melakukan tanya jawab secara langsung mengenai masalah yang akan dikerjakan pada bagianbagian yang terkait.

3. Studi Kepustakaan

Teknik pengumpulan data secara teoritis dengan bantuan bermacammacam buku yang berhubungan dengan masalah - masalah yang dibahas, seperti : buku - buku, artikel, dan lain- lain.

\section{Tujuan Penelitian}

Tujuan dari penulisan tugas akhir ini berdasarkan rumusan masalah yang telah dikemukakan di atas adalah :

1. Membuat sebuah aplikasi ECommerce berbasis Web untuk pengelolaan perekrutan member yang dapat diakses oleh semua user yang terhubung kedalam Web server

2. Member dapat melakukan pemesanan pembelanjaan produk secara Online dan hasilnya akan diterima oleh admin.

3. Point akan dihitung secara otomatis oleh aplikasi berdasarkan pemesanan produk yang dilakukan oleh member.

4. Aplikasi dapat menghitung level member secara otomatis berdasarkan total point yang diperolehnya.

5. Seluruh data pembelanjaan, point, level yang dilakukan oleh member dapat dilihat oleh seluruh member dan manajer.

\section{A. E-Commerce}

Pengertian mengenai E-Commerce sesungguhnya memiliki arti yang luas. Oleh karena itu, istilah E-Commerce dapat diartikan sebagai cara untuk menjual dan membeli barang (dan jasa) melalui jaringan internet, tetapi hal ini tentu saja mencakup berbagai aspek.

E-Commerce adalah sebuah konsep baru yang menjelaskan proses jual beli atau pertukaran produk, layanan, dan informasi melalui jaringan komputer termasuk Internet. (Kalakota, Whinston, Electronic Commerce A Managerial Persvective, 1997) mendefinisikan dari beberapa sudut pandang/ persfektif di bawah ini :

1. Dari persfektif komunikasi, EC merupakan pengiriman informasi, produk / jasa, atau pembayaran melalui

2. Dari persfektif proses bisnis, EC merupakan aplikasi teknologi menuju otomatisasi transaksi bisnis dan alur kerja.

3. Dari persfektif layanan, EC merupakan alat yang membahas keinginan perusahaan, konsumen, dan manajemen untuk memangkas biaya layanan sambil meningkatkan kualitas kbarang dan meningkatkan kecepatan pelayanan.

4. Dari persfektif Online, EC menyediakan kemampuan membeli dan menjual produk dan Informasi di Internet dan layanan Online lainnya.

\section{B. Analisis Sistem Berjalan}

Agar dapat menghasilkan sistem yang baik, tahap pertama yang harus dilakukan adalah mempelajari dan mengevaluasi sistem yang sedang berjalan. Pemahaman terhadap sistem yang sudah ada dengan mempelajari bagaimana sistem tersebut 
beroperasi. Adapun hal-hal yang dilakukan dalam menganalisis sistem yang sedang berjalan tersebut dengan meneliti hal-hal yang berhubungan dengan proses pengolahan data.

Untuk melaksanakan hal tersebut di atas, maka harus dilakukan beberapa tahapan dalam analisis sistem, yaitu :

1. Mengidentifikasi masalah, hal ini penting untuk mengetahui latar belakang dan batasan masalah.

2. Menganalisis sistem yang berjalan untuk mengetahui kemampuan sistem yang ada, ditinjau dari segi pola aliran informasi.

3. Mengevaluasi sistem yang diusulkan dan mengusulkan pemecahan masalah yang ada.

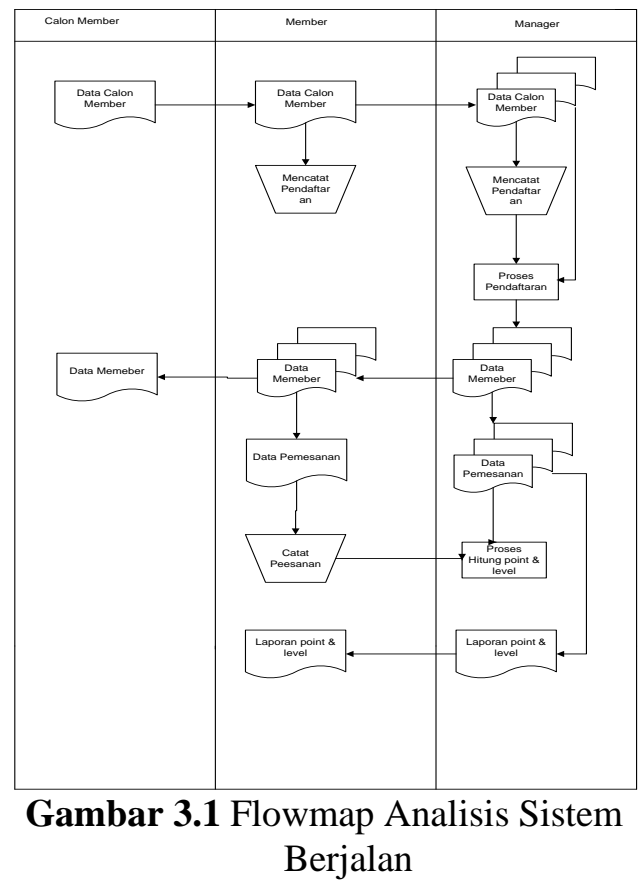

C. Analisis Sistem Diusulkan

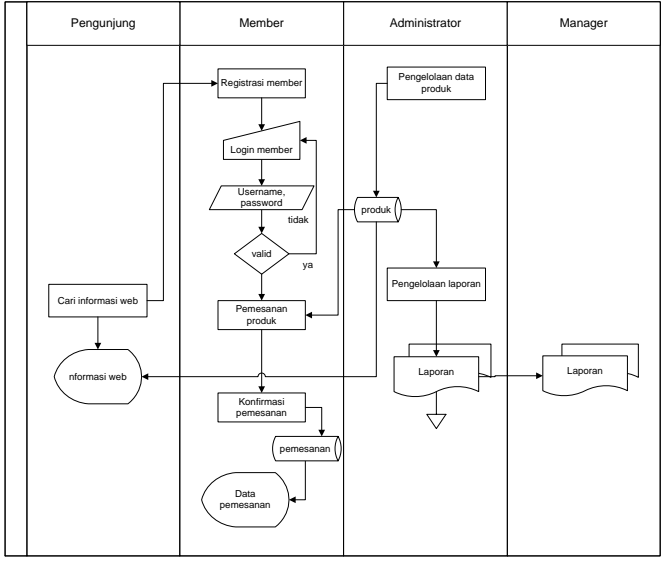

Gambar 3.3 Flowmap Sistem Diusulkan

\section{Diagram Konteks}

Diagram Konteks adalah sebuah diagram sederhana yang menggambarkan suatu sistem informasi secara global, termasuk aliran data dari masukan (input) dan keluaran (output) menjadi sebuah informasi yang terpadu.

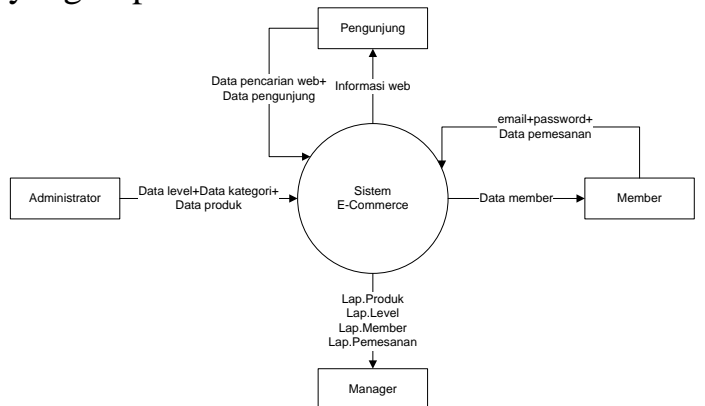

Gambar 3.4 Diagram Konteks

\section{E. DFD Level 0}

Data Flow Diagram merupakan gambaran sistem secara logika tanpa mempertimbangkan lingkungan fisik dimana data tersebut mengalir atau disimpan. DFD merupakan alat yang dapat mengambarkan arus data di dalam sistem secara terstruktur dan jelas. DFD level 0 untuk Sistem Informasi Pengelolaan Data Ayam Petelur terdapat pada gambar 3.5 dibawah ini.

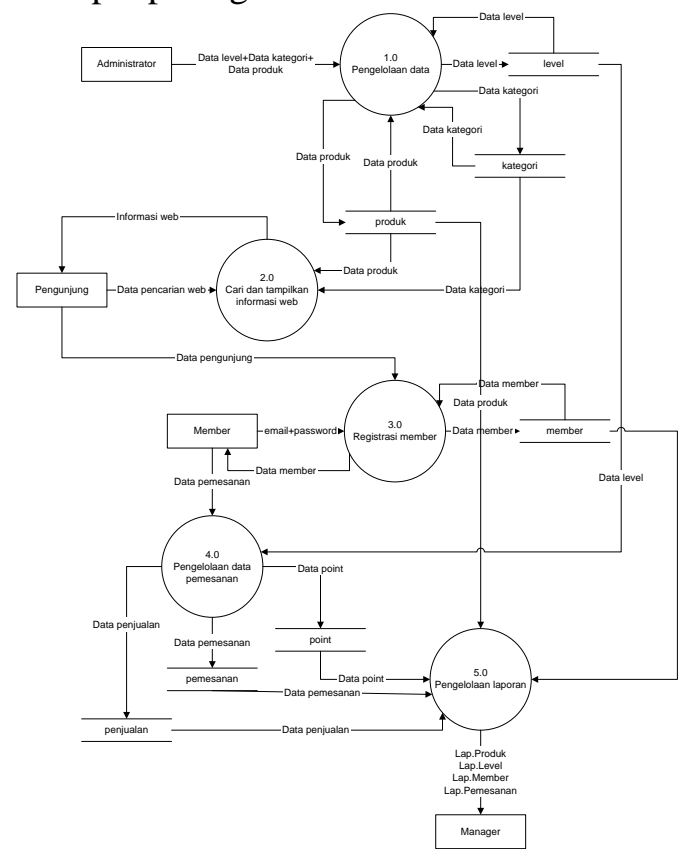

Gambar 3.5 DFD level 0 


\section{F. Entity Relationship Diagram (ERD)}

Pada model Entity-Relationship semesta data yang ada di dunia nyata diterjemahkan menjadi sekumpulan obyek dasar yang disebut entitas (entity) dan relasi antara obyek-obyek tersebut (relationship). Kedua komponen dasar ini didepenelitiankan lebih jauh melalui sejumlah atribut. Entity Relationship diagram (Diagram E-R) adalah gambaran keseluruhan struktur logis dari sebuah basis data.

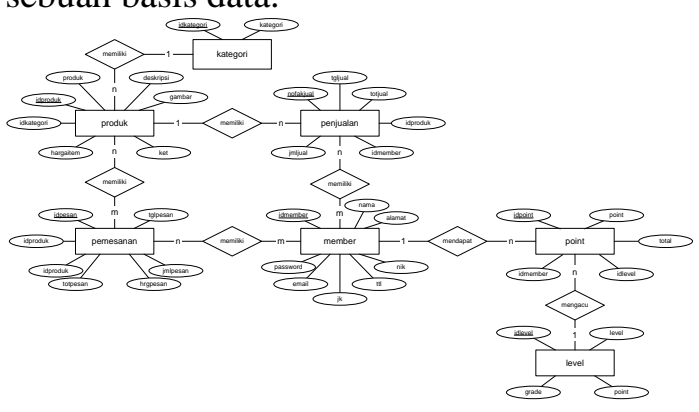

Gambar 3.6 ERD

\section{Implementasi Sistem}

Implementasi adalah tahap penerapan hasil perancangan yang prosesnya diuraikan sebelumnya. Implementasi yang dilakukan antara lain adalah menerapkan perancangan antarmuka ke dalam bentuk aplikasi, perancangan struktur data kedalam bentuk tabel database, pembuatan kode program dan sebagainya.

\section{Hasil Pengujian White Box

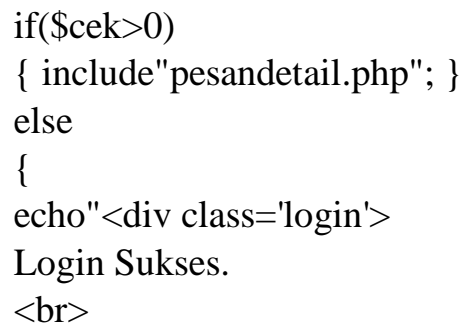

Penterjemahan pseudo code diatas ke grafik alir yaitu sebagai berikut:

$$
\text { if }(\$ c e k>0)
$$

\{ include"pesandetail.php"; \} else

echo"<div class='login'>

Login Sukses.

<br>

Silahkan

Lakukan

Pemesanan Online

$<$ br $></$ div";

endif

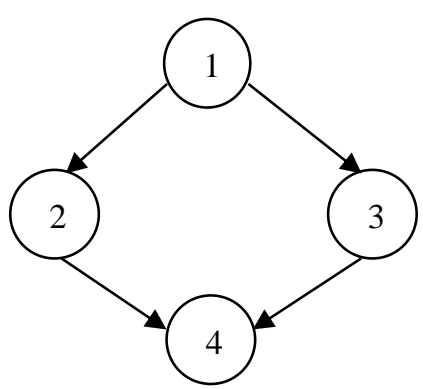

\section{Gambar 4.2 Flow Graph Kode Program}

Cyclomatic Complexity dari flow graph diatas dapat diperoleh dengan menghitung daerah yang dapat dibentuk oleh graph yaitu sebanyak 2. Atau bisa juga dihitung dengan menggunakan rumus $\mathrm{V}(\mathrm{G})$

$=\mathrm{E}-\mathrm{N}+2$ atau $\mathrm{V}(\mathrm{G})=\mathrm{P}+1$

Diketahui : E (jumlah edge pada flowgraph) $=4$

$\begin{aligned} \mathrm{N} & \text { (jumlah Node pada }\end{aligned}$ flow graph) $=1$

P (jumlah predikat Node pada

$$
\begin{aligned}
\operatorname{Maka} \mathrm{V}(\mathrm{G}) & =\mathrm{E}-\mathrm{N}+2 \\
& =4-4+2 \\
& =2
\end{aligned}
$$

$$
\begin{aligned}
\operatorname{Atau} \mathrm{V}(\mathrm{G}) & =\mathrm{P}+1 \\
& =1+1 \\
& =2
\end{aligned}
$$

Dari hasil perhitungan cyclomatic complexity terdapat 2 path ( jalur ) yaitu:

Path 1: $1-2-4$

Path 2: $1-3-4$

Berikut merupakan test case yang dilakukan terhadap kedua jalur tersebut:

Test case jalur ( path ) 1

- Input valid/ nilai = true

- Hasil yang diharapkan = Sistem akan membuka atau memunculkan halaman pesandetail.php 


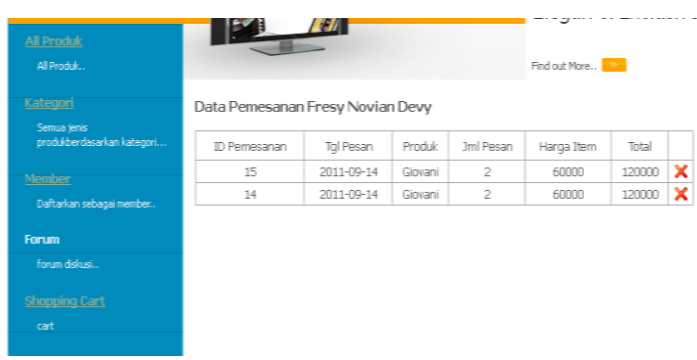

Gambar 4.3 halaman pesandetail

Test case jalur / 2

- Input valid / nilai false

- Hasil yang diharapkan = Sistem akan memunculkan pesan Login Sukses

เan.

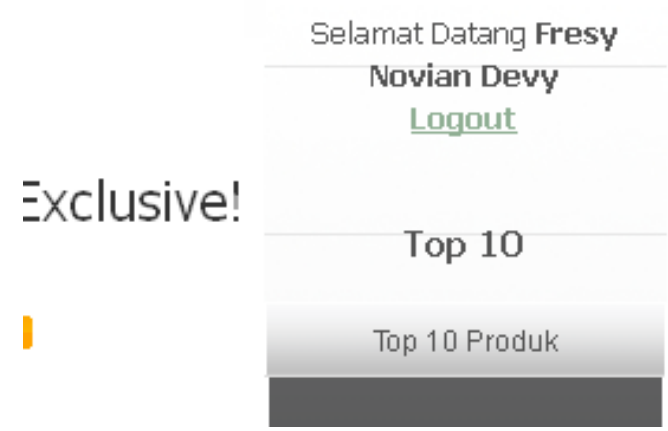

Gambar 4.4 Login

\section{Antar Muka (interface) program}

Pada tahap implementasi, untuk menjalankan program yaitu dengan menjalankan aplikasi dengan memasukan pada browser dengan alamat http://localhost/oriflame.

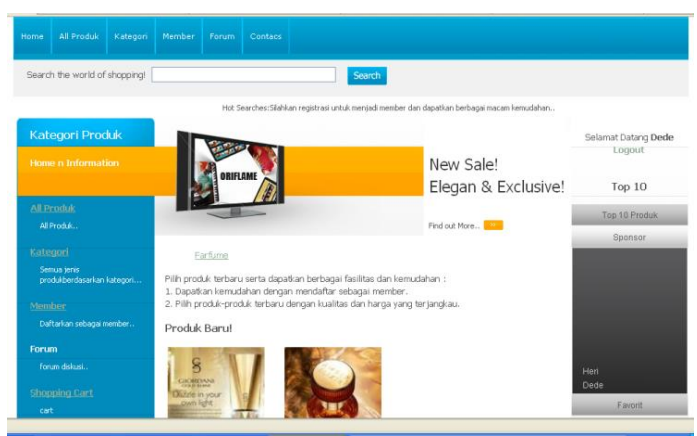

\section{Gambar 4.5 Halaman Index}

\section{Data Produk}

Pada tampilan ini user dapat melakukan pemesanan produk dengan melihat dan memilih produk yang tersedia.
Produk yang dipesan akan masuk kedatabase pemesanan produk.

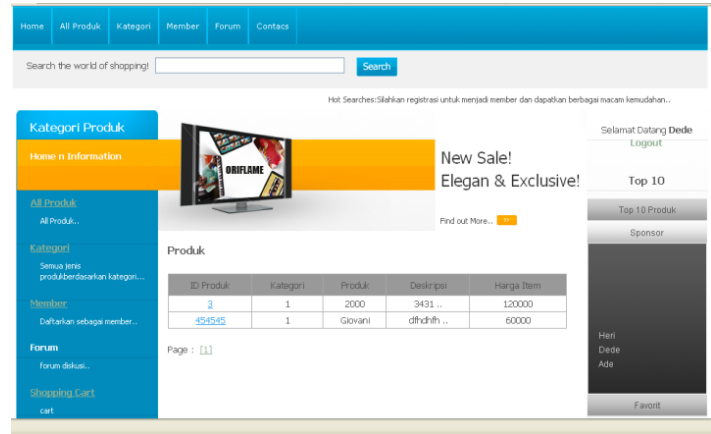

\section{Gambar 4.6 Data Produk}

\section{Form Member}

Tampilan member digunakan oleh member untuk melakukan pendaftaran melalui sponsor yang telah dipilih sebelumnya.

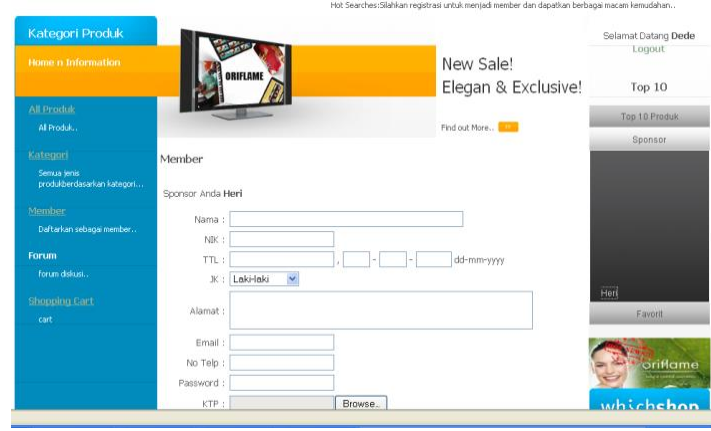

Gambar 4.7 Member

\section{Detail Produk}

Tampilan detail produk digunakan untuk melihat dan menampilkan detail produk sebelum dilakukan pemesanan.

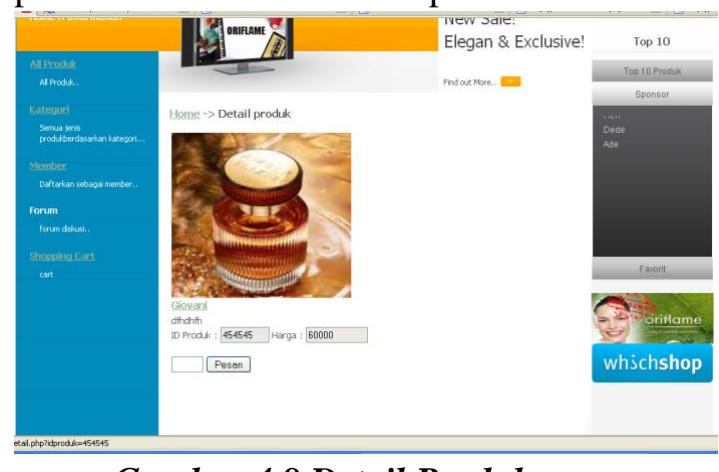

Gambar 4.8 Detail Produk

\section{Data Pemesanan}

Data pemesanan yang telah dilakukan oleh user akan ditampilkan dalam cart data pemesanan. 


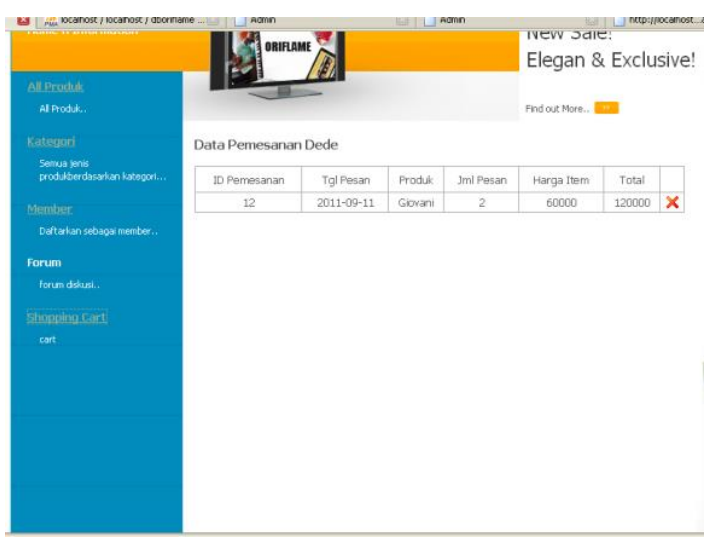

Gambar 4.9 Data Pemesanan

\section{Data Kategori}

Tampilan data kategori digunakan untuk melakukan pengelolaan data kategori yang dilakukan oleh admin. Data ini akan disimpan dalam tabel kategori.

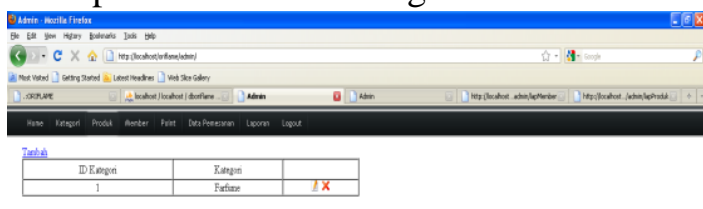

\section{Gambar 4.10 Data Kategori}

\section{Data Produk}

Tampilan data kategori digunakan untuk melakukan pengelolaan data kategori yang dilakukan oleh admin. Data ini akan disimpan dalam tabel kategori.

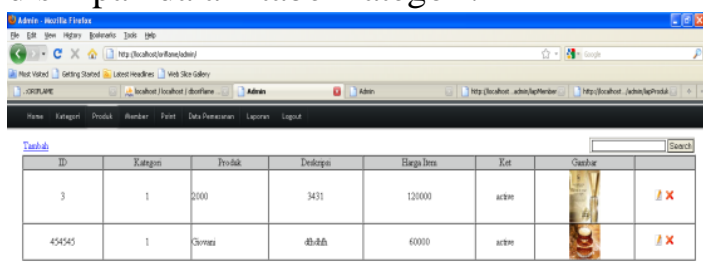

\section{Gambar 4.11 Data Produk}

\section{Data Member}

Tampilan data member digunakan untuk melakukan pengelolaan data member yang dilakukan oleh admin. Data ini berasal dari member yang melakukan pendaftaran.

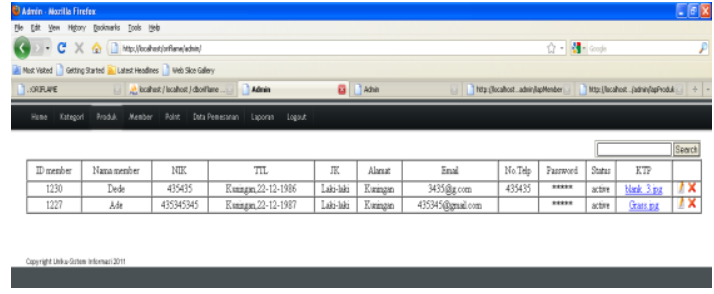

Gambar 4.12 Data Member

\section{Data Point}

Tampilan data point digunakan untuk melakukan pengelolaan data point yang dilakukan oleh admin. Data ini berasal dari point score yang diberikan untuk setiap pemesanan yang dilakukan member.

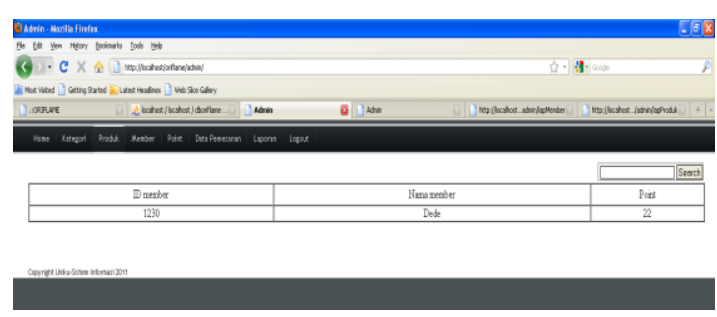

\section{Gambar 4.13 Data Point}

\section{Data Pemesanan}

Tampilan data pemesanan berasal dari data pemesanan yang telah dilakukan olem member. Data pemesanan ini akan disimpan dalam tabel pemesanan.

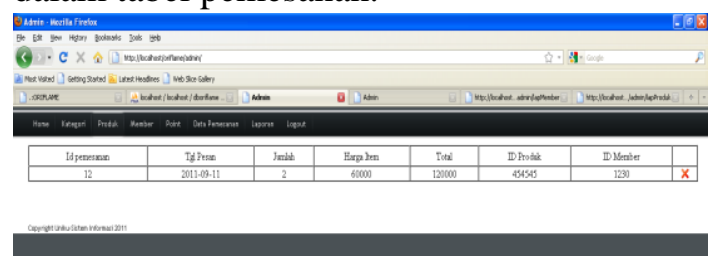

Gambar 4.14 Data Pemesanan

\section{Laporan Produk}

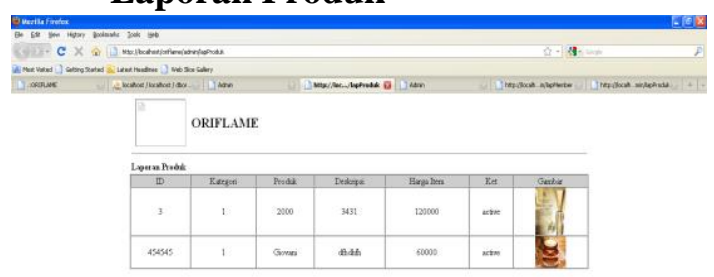

Gambar 4.15 Laporan Produk 


\section{Laporan Point}

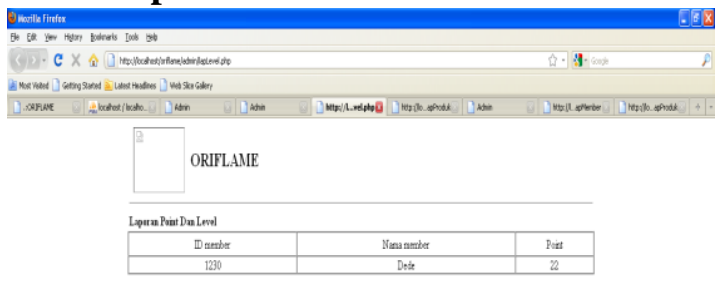

Gambar 4.16 Laporan Point

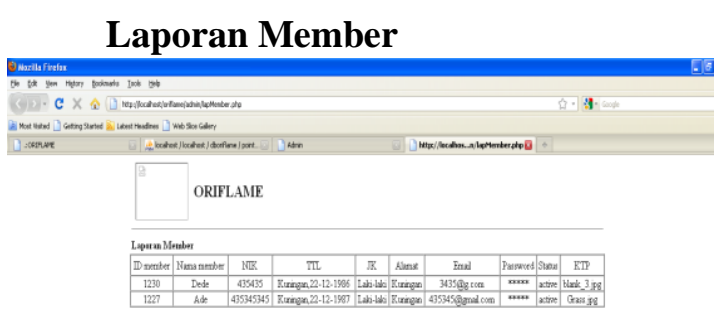

Gambar 4.16 Laporan Member

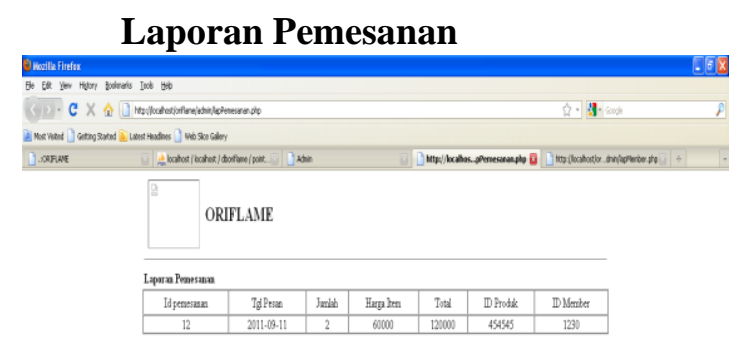

Gambar 4.17 Laporan Pemesanan

\section{Penutup}

\subsection{Kesimpulan}

Berdasarkan hasil pembuatan aplikasi dan pembahasan mengenai Aplikasi Perekrutan dan Pengelolaan Anggota Berbasis E-Commerce pada Kegiatan MLM Oriflame yang menggunakan konsep konsep ERD dan normalisasi, maka penulis mencoba untuk mengemukakan beberapa kesimpulan dalam pembuatan penelitian ini sebagai berikut :

1. Dengan adanya aplikasi Perekrutan dan Pengelolaan Anggota Berbasis E-Commerce pada Kegiatan MLM Oriflame ini dapat membuat member lebih mengerti terhadap proses bisnisnya.

2. Dengan adanya aplikasi Perekrutan dan Pengelolaan Anggota Berbasis E-Commerce pada Kegiatan MLM
Oriflame ini dapat membuat member mudah menerima Informasi yang terkadang mendapatkan banyaak kendala.

3. E-Commerce ini dapat menyelesaikan masalah manajemen pada suatu network grup Kegiatan MLM Oriflame.

4. Dapat memperudah perekrutaan jaringan yang terkadang sulit karena keterbatasan wilayah.

\subsection{Saran}

Berdasarkan hasil kerja pembuatan aplikasi, dan analisis serta perancangan yang dibuat, maka penulis mencoba mengemukakan beberapa saran antara lain :

1. Adanya aplikasi Perekrutan dan Pengelolaan Anggota Berbasis E-Commerce pada Kegiatan MLM Oriflame ini disarankan kepada manajemen dan member meningkatkan keterampilan komputer sehingga akan lebih efisien dalam penggunaan aplikasi ini.

2. Agar meningkatkan jaringan dan saling mengerti antara manajemen grup dan member sehingga member lebih mudah untuk mendapatkan informasi.

\section{DAFTAR PUSTAKA}

- Cahyono, Setiyo (2006). Panduan Praktis Pemrograman Database Menggunakan MySql Bandung : CV Informatika

- Fathansyah Ir. (1999). Basis Data. Bandung : CV.Informatika

- Jogiyanto HM (2000). Analisis dan Desain Sistem Informasi. Yogyakarta. : Andi Offset.

- Kadir, Abdul (2003).Pengenalan Sistem Informasi.Yogyakarta : Andi.

- Hariyanto, Bambang, Ir.MT. (2004).Sistem Manajemen Basis Data. Bandung : CV.Informatika 
- Pressman, Roger, Ph.d, Rekayasa Perangkat Lunak, Andi Yogyakarta 2002.

- Sutabri, Tata, Analisa sistem Informasi, Andi 2004.

- Hartono, Jogiyanto (2005). Analisis Dan Desain Informasi : Pendekatan Tersturktur teori dan Praktik Aplikasi Bisnis. ED III. Yogyakarta : Andi.

- Kadir, Abdul (2003). Konsep dan Tuntutan Praktis Basis Data. Yogyakarta : Andi

- Kristanto, Andi (2003). Perencangan Sistem Informasi dan Perancangannya.

- Yogyakarta : GAVA MEDIA

- Sidik, Betha Ir. (2004). Pemrograman Web dengan PHP. Bandung: Informatika. 
